\title{
A Comparative Study of Proverbs' Characteristics of Mesopotamian Language, and a Local Dialect of Persian
}

\author{
Mohammad Shariati \\ Islamic Azad University, Jiroft Branch, Iran \\ E-mail: mohammad_shariati@hotmail.com \\ Seyed Mohammad Tayebi \\ Shahid Bahonar University of Kerman, Iran
}

Received: July 1, 2011

Accepted: September 6, $2011 \quad$ Published: April 1, 2012

doi:10.5539/ijel.v2n2p141

URL: http://dx.doi.org/10.5539/ijel.v2n2p141

\begin{abstract}
Different types of comparative studies of proverbs have, so far, been carried out, but no geolinguoistic or historical or in other words diachronic or synchronic studies of the characteristics of proverbs have been recorded. The present study has compared the proverbs of two different historical sites viz. Mesopotamia and Jiroft. As the proverbs of Mesopotamian language were already studied, their characteristics were used as a yardstick to consider those of a remote local dialect of Persian. The results proved the viability of the previous studies and the correspondence of those characteristics in the languages under scrutiny. The data were collected through field work.
\end{abstract}

Keywords: Proverb, Mesopotamian, Persian, Sardooieeh (n), Sardooyee (adj)

\section{Introduction}

Proverbs are said to be an intuitive aspect of adults' mental functioning. How they are used and understood is maintained to be less intuitive. Because proverbs are complex, an interdisciplinary perspective is needed to explain how people use and understand them. Cognitive science provides our best prospect for revealing the secrets of the proverb. (Honeck, 1997)

Sometimes, proverbs are included in the list of forms of figurative speech. Honeck (ibid) has considered metaphor, simile, idiom, metonymy, and oxymoron the major alternatives. He has addedthat some scholars would include sarcasm, irony, hyperbole, understatement, and rhetorical questions, although these are said to be better treated as linguistic functions than as unique linguistic forms. Elsewhere, they are defined as 'the wisdom of many, the wit of one' (Dundes, 1981), oras figurative expressions that capture the shared beliefs and values of a society (Nipold \&.Haq, 1996).More recently, Hagopian (2008) stated that proverbs are folk sayings common in use and pithy in sense and structure; they contain a special conclusion or recommendation in regard to almost every life situation.

Moreover in American Heritage Dictionary (2001) proverb is defined as: "A short pithy saying in frequent and widespread use that expresses a basic truth or practical precept." Also in Oxford Dictionary of Literary Terms (2008) it is defined as "a short popular saying of unknown authorship, expressing some general truth or superstition."

Different types of comparative studies of proverbs have, so far, been carried out. The first detailed study that critically compared and contrasted the wisdom sentences of the Book of Proverbs with classical and post-classical Arabic proverbs was by Kassis, (1999). In his work, reference is made to current Arabic proverbs.

In a review of the book by Williams (2000 p. 151) it is stated that,

"It is rather surprising, given the quantity of secondary literature spawned by the comparison of biblical proverbs with those of other cultures, that so little has been written about the relationship between biblical proverbs and Arabic ones. Kassis's pioneering survey of extensive corpora of Arabic sayings that elucidate biblical material is therefore invaluable." 
As mentioned before, proverbs of different cultures have been collected and sometimes compared. However, comparing characteristics of proverbs of different cultures is still in need of attention, because this would pave the way to come up with a set of universal characteristics for proverbs.

Scholars have, separately, tried to identify the characteristics of proverbs as multifunctional linguistic forms to understand them more objectively. To verify validity of such proposed characteristics in Persian and hence to carry out a comparative investigation, this study has aimed at analyzing a sample of proverbs of a local dialect of this language. To this end, a list of proverbs was collected from a rural parish of Jiroft, i.e. Sardooiyeh. The significance of the area is in that the language is less changed than the Tehrani Persian of today, and is close to early Modern Persian. Moreover, it was to see if proverbs from remote areas would prove the proposed assumptions about proverbs.Not to mention that Jiroft is the area recently introduced for the fact that archeological studies on the coals gathered during excavations in there has revealed that Iran's stone art was more developed than that of Mesopotamia around $2800 \mathrm{BC}$. It also proved that the surface layer of this historical site is more than 4800 years old. Furthermore, the researcher is a speaker of the dialect under investigation.

\section{Review of literature}

It is generally accepted that the proverbs and sayings of a people show their national character and personality traits. Buchanan (1965, p. xiii) quoted the English philosopher Sir Francis Bacon to have observed nearly four hundred years ago that "the genius, wit and spirit of a nation are discovered in its proverbs," Also of about the same time the Spanish writer Miguel de Cervantes to have remarked that "proverbs are short sentence drawn from long experiences,' He has reported the English Quaker William Penn who commented one hundred years later: "The wisdom of nations lies in their proverbs, which are brief and pithy.", and Benjamin Disraeli, as one of the keenest minds of the nineteenth century, who stated that proverbs were anterior to books and formed the wisdom of the vulgar, and that in the earliest ages they were the unwritten laws of morality."

The earliest collections of proverbs can be traced as far back as ancient Egypt, about 2500 B.C. The Old Testament attributed some 900 proverbs to King Solomon (10th century B.C.). The first person, however, to engage more systematically in the collation and classification of proverbs was the Greek philosopher Aristotle (384-322 B.C.). According to the neo-Platonicphilosopher Synesius (A.D.370-413), Aristotle considered proverbs a survival of an older wisdom: 'Proverbs are... elements of old philosophy which survived thanks to their brevity and dexterity.' (Karagiorgos, 1999)

As the main concern of this paper has not been mere collection but identifying the characteristics of proverbs, a number of works were chosen and introduced below to be used as the measure against which the specifications of the proverbs of the above mentioned local dialect of Persian could be examined. That is, works that have introduced and classified some characteristics of proverbs somewhat objectively. The following accounts were selected both for theoretical and empirical basic information of the readers, and the development of the instrument for the comparatist (researcher).

One such classification of the characteristics of proverbs was suggested in the following quote: "Two basic characteristics differentiate proverbs generally from freely formed utterances. First, proverbs are preformed, inventorized linguistic units; and second, they are traditional items of folklore. (Norrick, 1985, p. 25)"

Two consequences are mentioned for the former characteristic; first, they are available as preformed utterances which meet the speaker's need for formulating an original utterance of his/her own. Also, they are readily available in recurrent situations which "call for stock formulas" (ibid). Second consequence is maintained to be their value in signaling group membership, e.g. one can signal his membership in and identification with local village community by using the shared dialectal proverbs.

In another study, Marianna \& Vogelzang, (1996, p. 2) maintained that:

Proverb is an anonymous miniature piece of verbal art, used rhetorically to highlight an argument relating to human behavior. It is recognizability of the saying, often combined with the linguistic delight involved in manipulating figurative speech, metaphors and humorously exaggerated categorical statements; ... , proverbs are unsystematic; they may contradict each other; and their purpose is not primarily to give moral instruction, but rather to support an argument by referring to what is tacitly assumed to be commonly accepted knowledge, whether or not the point is moral. In addition, proverbs fulfill a function as entertainment and linguistic pleasure. 
In the same text, a series of characteristics of Mesopotamian poeticlanguage was identifiedwhich were summarized and listed below.

Proverbs

- Practiced rhetorical techniques

-Were used for instruction, in a wide sense to implant a specific attitude.

- Not only are indicative of a specific cultural heritage, but they are international

- Stand apart from the diction created by literate, in that they fundamentally belong to the spoken language.

- were not coined by academics; do not express learned philosophical ideas. Their origin is to be found in the speech of ordinary people

Furthemore, Lauhakangas, (2007, p. 5) stated:

Proverbs are multifunctional and flexible instruments of everyday reasoning, although they may maintain solidified attitudes or traditional modes of thought of a certain culture. A proverb can be considered as a piece of advice concerning a recommended direction of action (although it is not literally a piece of advice). Proverbs are propositions loaded with hidden feelings, wishes and intentions of the speaker. They can serve as tools to cover individual opinions in public interactive situations. Like in rhetoric in general the proverbs we use in our speech (and in our inner speech, too) protect our personal attitudes by appealing to an authority.

The ability to use proverbs leans on common rules and recipes and it is a part of facilities for outlining and organizing quickly and effectively things which we experience in everyday situations. Reasoning, classifying, comparing and explaining are mechanisms by which people aim at while creating hierarchy and consistency to the contents of commonplace thinking.

Some of the mentioned Characteristics were extracted to be codified and added to the list.

- Proverbs are multifunctional and flexible instruments of everyday reasoning, (MIR)

- Proverbs may maintain solidified attitudes or traditional modes of thought of a certain culture (MSA)

- A proverb can be considered as a piece of advice concerning a recommended direction of action (although it is not literally a piece of advice) (CAPA)

\section{Methodology}

\subsection{Sampling}

The sample comprised 150 proverbs collected through field research into folk literature of a parish of the ancient city of Jiroft (south east of Iran) called Sardooiyeh.

The process included two phases: collection of some more inclusive data on folk literature and reduction of data by classification into vocabulary and proverbs. Vocabulary was considered in another paper. Proverbs were accounted for here in this study.

\subsection{Instrumentation}

The yardstick against which the sample proverbs were assessed was developed by the researcher listing some of the implicit and explicit characteristics proposed in literature on proverbs. Marianna \& Vogelzang, (1996, p. 2), Norrick, (1985, p. 25 and Lauhakangas, (2007, p. 5) have been the main sources of classification for this purpose. They were, ofcourse, distiguished as specific and general,and were codified as in the following for the ease of management in the tables.

\subsubsection{Specific to Mesopotamian}

- Practiced rhetorical techniques (PRT)

- Were used for instruction, in a wide sense to implant a specific attitude. (UFI) 
- Not only they are indicative of a specific cultural heritage, but they are international. (IOCH\&I)

- They stand apart from the diction created by literate, in that they fundamentally belong to the spoken language. (FSL)

- They were not coined by academics; do not express learned philosophical ideas. Their origin is to be found in the speech of ordinary people. (FISOP)

\subsubsection{General}

- They are preformed inventorized linguistic units. (PILU)

- They are traditional items of folklore. (TIOF)

- Proverbs are multifunctional and flexible instruments of everyday reasoning, (MIR)

- Proverbs may maintain solidified attitudes or traditional modes of thought of a certain culture. (MSA)

- A proverb can be considered as a piece of advice concerning a recommended direction of action (although it is not literally a piece of advice) [CAPA]

Procedure of assessment was manual. That is, the researcher looked for possible examples for each of the characteristics in the list.

\section{Findings}

As mentioned before, the characteristics listed above were used as yardsticks to see if the list of proverbs collected in our area under investigation would confirm the claim or not. The following table shows an example from our data for each of the characteristics.

\begin{tabular}{|c|c|}
\hline Specific & \\
\hline PRT & [ hær bą̌̆aki dārəfæaňaki] \\
\hline UFI & $\begin{array}{l}\left.\text { [na beda dærvi } \int \text {, na bezæn dærvi } \int\right] \text { Neither give anything to the beggar nor beat } \\
\text { him }\end{array}$ \\
\hline IOCH\&I) & [bəlæd nï bəexsa migg zaminæ kajæn] Can't dance, says the floor is uneven. \\
\hline FSL & $\begin{array}{l}\text { [az xorūs xūn tā tüla xūn kār mïkona] he works from when the cocks sing till when } \\
\text { jackals how. }\end{array}$ \\
\hline FSL & 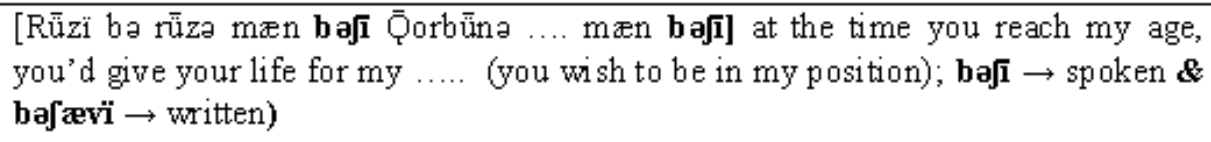 \\
\hline FISOP & $\begin{array}{l}x æ r \text { oü } x \text { eriya tü } x æ r g e l a x \text { ode } \int \text { besærra (It is good donkey that brays in its own } \\
\text { herd) }\end{array}$ \\
\hline General & \\
\hline PILU & $\begin{array}{l}\text { Proverbs here show this people's life style: living on animal husbandry and } \\
\text { agriculture (in addition to instruction, advice, etc.) }\end{array}$ \\
\hline TIOF & All examples were constituens of folk literature \\
\hline MIR & $\begin{array}{l}\text { hama konæn yārï dalæk kona xona dārï everyone should help till one develops a } \\
\text { family }\end{array}$ \\
\hline MSA & This one overlaps PILU \\
\hline CAPA & $\begin{array}{l}\text { [na beda dærvi[ }\left[\text {, na bezæn dærvi } \int\right] \\
\text { Neither give anything to the beggar nor beat him }\end{array}$ \\
\hline
\end{tabular}




\section{Discussion}

\subsection{Practice of rhetorical techniques}

In Mesopotamian poetic language rhetorical techniques were practiced.Similarly, they have been practiced in the area under present study.To verify and show thepractice of rhetorical techniques in detail, the data were examined against a list of literary terms as follows:

Accumulation is a figure of speech in which a speaker or writer gathers scattered points and lists them together.

The sun sets and rushes back again to the place from which it rises. (Ecclesiastes, The Old Testament)

Sardooyee Persian: [donyā mïđzomma wā mïđzomma sar dzāy xodfa migira] = the world wobbles and settlesdown and finally resides in its initial position

Accismus is a form of irony where one pretends indifference and refuses something while actually wanting it. In Aesop's fable, the fox pretends he doesn't care for the grapes. (AnuGarg at Wordsmith.org)

Sardooyee Persian: [gorba dastaf ba gü]t namiresa mïga bü mïda] = the cat couldn’t reach the meat says it stinks

Antimetabole is a verbal pattern in which the second half of an expression is balanced against the first but with the words in reverse grammatical order (A-B-C, C-B-A).

We didn't land on Plymouth Rock; Plymouth Rock landed on us. (Malcolm X)

Sardooyee Persian: [mā ïnäya baxorim yäïnä māyə] = should we be eaten by these or eat them (stated when one doesn't have appetite and is offered something)

Antithesis: is a rhetorical term for the juxtaposition of contrasting ideas in balanced phrases or clauses.

Hillary has soldiered on, damned if she does, damned if she doesn't,

Sardooyee Persian: [ $t$ Ærwat konan mïğrrï, nærmat konan mïğgrï] $=$ you groan whatever the condition!

Analogy, in rhetoric, is reasoning or explaining from parallel cases. A simile is an expressed analogy; a metaphor is an implied one.

Sardooyee Persian: [tar af mesla ₹era dehgähïya] = the guy is like a donkey from low lands, [that couldn't climb the mountains]

Anadiplosis (1.5\%): ("doubling back") the rhetorical repetition of one or several words; specifically, repetition of a word that ends one clause at the beginning of the next.

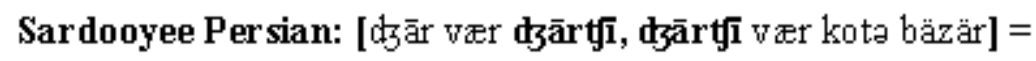

Parallelism (25\%): Figure of balance identified by a similarity in the syntactical structure of a set of words in successive phrases, clauses, sentences; successive words, phrases, clauses with the same or very similar grammatical structure.

examples:

We are bound by ideals that move us beyond our backgrounds, lift us above our interest, and teach us what it

[ har b aňaki dāra fæen̆aki]

[küra xodet o bïnäya mardamï] vï na bezan darvï]] = give him not, beat him not [narähï r afta ne zälï derda]

Parallelism is used in over $25 \%$ of the cases under scrutiny. 
Paradox: an assertion seemingly opposed to common sense, but that may yet have some truth in it.

Sardooyee Persian: [raspon ei hamüjäi kol oft tare mit]îla]

Metaphor: implied comparison achieved through a figurative use of words; the word is used not in its literal sense, but in one analogous to it. \& Personification.

SardooyeePersian: [tüleikətüksüz] $=$ the Jackal who sets the hut aflame $=$ the trouble maker

Antistrophe (4\%): repetition of the same word or phrase at the end of successive clauses.

SardooyeePersian: [ $\left[\right.$ a beda dærvi $\int$, na bezæn dærvi $\left.\int\right]=$ Be neither intimate nor distant with the clergy.

Assonance(4\%): repetition of the same sound in words close to each other.

SardooyeePersian: [[na zür zeda, na zärï, bachei golengï dərï] $=$

Anaphora(7\%): the repetition of a word or phrase at the beginning of successive phrases, clauses or lines.

SardooyeePersian: [na beda darvï, na bezæn darvï] =
A. Anaphora $=7 \%$
B. Anadiplosis $=1.5 \%$
C. Antistrophe $==4 \%$
D. Assonance $==4 \%$
E. Parallelism $=25 \%$

5.1.1 The use of proverbs for instruction

In the literature, proverbs were reported to be used for instruction, in a wide sense to implant a specific attitude. Examples from our study are:

\begin{tabular}{|l|l|l|}
\hline$[$ hær bøn̆əki dāra fær̆əki] & $\begin{array}{l}\text { Keep a thing for seven years and you'll find a use } \\
\text { for it. } \\
\text { Irish Proverb }\end{array}$ \\
\hline $\begin{array}{l}\text { Every shred has its technique } \\
\text { Neither give anything to the begger nor beat } \\
\text { him }\end{array}$ & $\begin{array}{l}\text { Be neither intimate nor distant with the clergy. } \\
\text { Irish Proverb }\end{array}$ \\
\hline
\end{tabular}

5.1.2 Proverbs are international

The above example also shows that proverbs are not only indicative of a specific cultural heritage, but they are international. This is the next characteristic listed above for which more examples are given below:

\begin{tabular}{|c|c|}
\hline $\begin{array}{l}\text { [Dïgïkənədāræmbæhrəxā kæhrəxā bærə] } \\
\text { (In the pot from which I don't have a share, be } \\
\text { it lamb or be it goat.) }\end{array}$ & $\begin{array}{l}\text { It is an ill wind that blows nobody any good. } \\
\text { Proverb of Unknown Origin }\end{array}$ \\
\hline $\begin{array}{l}\text { [bəlædnïbəexsəmïgəzəmïnækəjæn] } \\
\text { (Can't dance, says the floor is uneven) }\end{array}$ & $\begin{array}{l}\text { The girl who can't dance says the band can't } \\
\text { play. } \\
\text { Yiddish Proverb }\end{array}$ \\
\hline 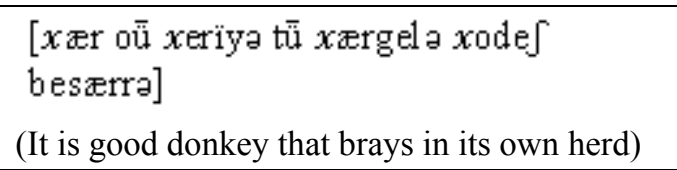 & $\begin{array}{l}\text { It is the good horse that draws its own cart. } \\
\text { Irish Proverb }\end{array}$ \\
\hline $\begin{array}{l}\text { [āsuda kəsi kə } x \text { ær nadāra æz kaho } \\
\text { jəwə] } x \text { əvær nadārə] } \\
\text { (calmfortable is he who has no donkey, 'cause }\end{array}$ & He who knows nothing, doubts nothing \\
\hline
\end{tabular}




\begin{tabular}{|l|l|l|}
\hline $\begin{array}{l}\text { he worries not of hey and barly) } \\
\text { adæmə go } \int \text { ñə ïmon nədærə } \\
\text { (A hungry man has no faith) }\end{array}$ & $\begin{array}{l}\text { A hungry man is an angry man. } \\
\text { English Proverb }\end{array}$ \\
\hline $\begin{array}{l}\text { māləmærdommāləmærdomə } \\
\text { (possession of others is possession of others) } \\
\text { Sarcastic way of saying: } \\
\text { (Old loan was waivered by the king) }\end{array}$ & $\begin{array}{l}\text { A loan though old is not a gift. Hungarian } \\
\text { Proverb }\end{array}$ \\
\hline
\end{tabular}

\subsubsection{Proverbs are spoken}

They stand apart from the diction created by literate, in that they fundamentally belong to spoken language.

Our examples are all colloquial. Most of them have used unmentionable expressions so straight forwardly that listing those needs euphemism or deletion. Like:

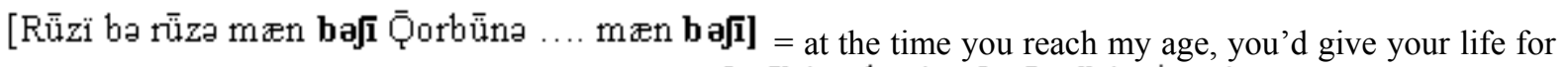
my ..... (Note 1) (you'd wish to be in my position); bafi (spoken) = bafavï (written)

\subsubsection{Proverbsare not coined by academics}

They are not coined by academics; do not express learned philosophical ideas. Their origin is to be found in the speech of ordinary people

They are common in rural areas and closely related to their life style and way of life e.g. animal husbandry and agriculture. Like:

[azxorūs $x$ ūntātǖləxūnkārmïkonə] (he works from when the cocks sing till when jackals howl.)

\subsubsection{Proverbs are multifunctional}

An example of multifunctionality could be depicted in the following diagram:

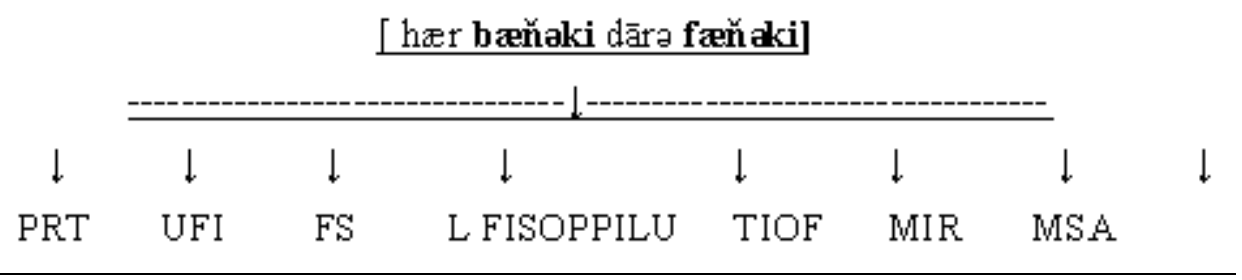

\subsection{Poetic aspect of this dialect as compared to Mesopotamian}

As Mesopotamian was called a poetic language in the literature reviewed above, examples regarding this specification of the dialect under study are provided below:
A. [āğà bəmirə dəgerdgə, bivï bəmirə dəgerdə, dəgerdey mā væməgærdə]
B. [na beda dærvi $[$, na bezæn dærvi]]
C. [Dïgï ka nadāræm bæhra $x \overline{\mathrm{a}} \mathrm{k} \nsim$ hra $x \overline{\mathrm{a}} \mathrm{b} \approx \mathrm{ra}]$

\begin{tabular}{|l|l|l|l|}
\hline A & bæn̆aki & fæn̆əki & rhyme \\
\hline B & bəmirə dəgerdə & bəmirə dəgerdə; væməgærda & rhyme; versification \\
\hline C & dærvi $\int$ & dærvi $\int$ & dærvi $\int$, versification \\
\hline D & bæhrə & kæhrə; bærə & dærvi $\int$; versification \\
\hline
\end{tabular}

\section{Conclusion}

This study proved that there are universal characteristics for proverbs, and they are intercultural and, of course, intra-cultural. The listed characteristics above, less explicitly stated in Marianna and Vogelzang. (1996), and Lauhakangas, (2007) are applicable to the proverbs of a rather remote arealike Sardooiyeh of Jiroft. 
Moreover looking from another angle, these characteristics which were traced back in Mesopotamian language were also found in a local dialect of Persian which belongs in the wider area of Jiroft city whose stone art proved recently to have been more developed than that of Mesopotamia around $2800 \mathrm{BC}$.

\section{References}

American Heritage Dictionary, (4 ${ }^{\text {th }}$ ed.). (2001). US: Houghton Mifflin Company.

Buchanan, D. C. (1965). Japanies proverbs and sayings. USA: University of OKlahoma Press.

Dundes. (1981). On the structure of the proverb. In W. Mieder and A. Dundes (Eds.), TheWisdom of many (pp. 43-64). New York: Garland Publishing Inc.

Gayané V. Hagopian. (2008). Armenian Proverbs and Biblical Scripture. Journal of the Society of Armenian Studies, 17, pp. 43-78.

Honeck, R. P. (1997). A Proverb in Mind: The Cognitive Science of Proverbial Wit and Wisdom. Mahwah, New Jersey London : LAWRENCE ERLBAUM ASSOCIATES.

Karagiorgos P. (1999). Greek and English Proverbs. Retrieved from: http://www.translatum.gr/etexts/pk/greek-proverbs.htm

Kassis, Riad Aziz. (1999). The book of Arabic proverbs and Arabic proverbial works. Boston: Brill.

Lauhakangas, O. (2007). Use of Proverbs and Narrative Thought. Folklore, Vol. 35, 77-84.

Marianna E. \&Vogelzang, H. L. (1996). Mesopotamian poetic language: Sumerian and Akkadian. STYX.

Nipold, M. A. (1996). Proverb comparison in youth. Journal of Speech and Hearing Research, 39, 166-176.

Norrick, N. R. (1985). How proverbs mean: semantic studies in English proverbs. Berlin: New York: Mouton. http://dx.doi.org/10.1515/9783110881974

Oxford Dictionary of Literary Terms ( $3^{\text {rd }}$ ed.). (2008). New York: OUP.

WilliamsP.J. (2000). A review of the book The book of Arabic proverbs and Arabic proverbial works, by R. A. Kassis. TynBul, 51(1), p. 151.

Note

Note 1. Fart 